\title{
Water column anoxia: vertical zonation of planktonic protozoa
}

\author{
Tom Fenchel ${ }^{1}$, Lisbet D. Kristensen ${ }^{2}$, Lise Rasmussen ${ }^{3}$ \\ ${ }^{1}$ Marine Biological Laboratory, University of Copenhagen, DK-3000 Helsingør, Denmark \\ ${ }^{2}$ Vejle Amtskommune, Forvaltningen for Teknik og Miljø, DK-7100 Vejle, Denmark \\ ${ }^{3}$ Teknik \& Miljøforvaltningen, Ringkøbing Amtskommune, DK-6950 Ringkøbing, Denmark
}

\begin{abstract}
The vertical zonation of planktonic protozoa was studied in 2 Danish eutrophic fjords at localities with an anoxic layer of bottom-water. Three distinct assemblages of protozoa are found. The fully oxygenated surface waters harbour a typical ciliate-plankton assemblage dominated by tintinnids and other oligotrichs in addition to various gymnostome ciliates. Heterotrophic flagellates totally dominate as bacterivores. In the oxycline a quite different group of ciliates occur; it is dominated by bacterivorous scuticociliates. Beneath the oxycline, in strictly anoxic and sulphide containing water, an assemblage of specialised anaerobic ciliates occurs. The high bacterial productivity in the oxycline is reflected by a biomass maximum of ciliates and to a lesser degree of heterotrophic flagellates. In anoxic microbial communities the biomass ratio between phagotrophs and their prey is much lower than in aerobic communities due to the low net growth efficiency of anaerobic eukaryotes. The potential significance of methane production by methanogenic symbionts of anaerobic protozoa is discussed.
\end{abstract}

\section{INTRODUCTION}

The water column of the sea is normally oxygenated from the air-water interface, and down to the sediment surface and there is usually a mm to $\mathrm{cm}$ thick surface layer of oxidised sediment as well. Under some circumstances, however, a permanent or transient stratum of anoxic and reduced water occurs. The Black Sea is permanently anoxic below a depth of 100 to $200 \mathrm{~m}$, and anoxia is also a characteristic of the Cariaco Trench, of deep Baltic basins, and of Norwegian fjords with a sill. Anoxic basins also occur in coastal waters and, in particular, in more or less landlocked bays, coves and estuaries. In the latter type of habitats, affected areas have recently tended to increase and this has been linked to eutrophication. Anoxic basins have drawn attention regarding their biogeochemical properties and their microbial (prokaryote) ecology, and the enhanced production of particulate organic material (POM) by chemolithotrophic bacteria in the chemocline (based on the oxidation of reduced sulphur compounds) has been studied in some detail. Where anoxia occurs, or is spreading in coastal waters, the adverse effect on fish and shellfish is a matter of concern (Kühlmorgen-Hille 1963, Richards 1965, Tulkki 1965, Oert- zen \& Schlungbaum 1972, Sorokin 1972, Indrebø et al. 1979, Jørgensen et al. 1979, Jørgensen 1980).

Within marine sandy-sediments the vertical chemical zonation is reflected by vertical zonation patterns of the interstitial microfauna and in particular of the protozoa. Fenchel (1969) demonstrated the existence of 3 main groups of ciliates: those occurring exclusively in the oxygenated surface layers, those occurring in the chemocline ('redox discontinuity layer') and finally an assemblage of anaerobic forms which live in a strictly anoxic and chemically-reduced environment. In stratified lakes with an anoxic hypolimnion a similar zonation pattern is found. When stratification is seasonal, the development of an anoxic hypolimnion is accompanied by an exodus of otherwise benthic ciliates which find their preferred oxygen tension in the water column and even the obligatory anaerobes become planktonic. The eukaryote plankton of hypoxic waters is almost, and in the case of anoxic water exclusively, composed by protozod (Goulder 1972, 1974, Finlay 1980, Bark 1981).

To our knowledge no description exists of the vertical zonation or composition of the microplankton in marine anoxic waters or in the overlying oxycline. Here we describe the plankton of 2 estuarine localities with 
anaerobic conditions above the sediment. Special emphasis is on the vertical zonation patterns of ciliates, the presence of microaerophilic and anaerobic species and the trophic role of the bacterial production in the chemocline.

\section{MATERIALS AND METHODS}

Study sites. Mariager Fjord is situated on the east coast of Jutland, Denmark (Fig. 1). It is ca $40 \mathrm{~km}$ long and there is a sill of only ca $1 \mathrm{~m}$ depth close to the entrance, but further inwards there are basins with depths down to $29 \mathrm{~m}$. We sampled in a basin which is ca $25 \mathrm{~m}$ deep; it is situated $28 \mathrm{~km}$ from the entrance of the fjord off the town of Mariager. The salinity is 13 to $15 \%$ at the surface and 19 to $21 \%$ at the bottom. The halocline (and during the summer a thermocline) is found at 10 to $13 \mathrm{~m}$ depth. The maximum density gradient coincided with an oxygen tension of ca $40 \%$ atm. sat. during the study period and is here considered as the top of the oxycline. Beneath this depth oxygen tension declines to reach zero values (Fig. 2). When the $\mathrm{pO}_{2}$ has fallen to a few percent, the redox potential falls from ca $0.4 \mathrm{~V}$ down to negative values over 1 to $2 \mathrm{~m}-$ coinciding with the presence of sulphide. We sampled the locality on 7 occasions during 1987 (April 14, May 5 and 23, June 22, July 12, August 3 and October 6) in addition to an incomplete sample taken in November. In April the water was only completely anoxic and sulphide-containing immediately above the sediment; during the summer the anoxic layer expanded up to $10 \mathrm{~m}$ above the bottom and the total sulphide concentration rose to about $1 \mathrm{mM}$ in the deepest samples. This suggests that the basin had been oxygenated during a storm or an event of inflow of saline water from the sea

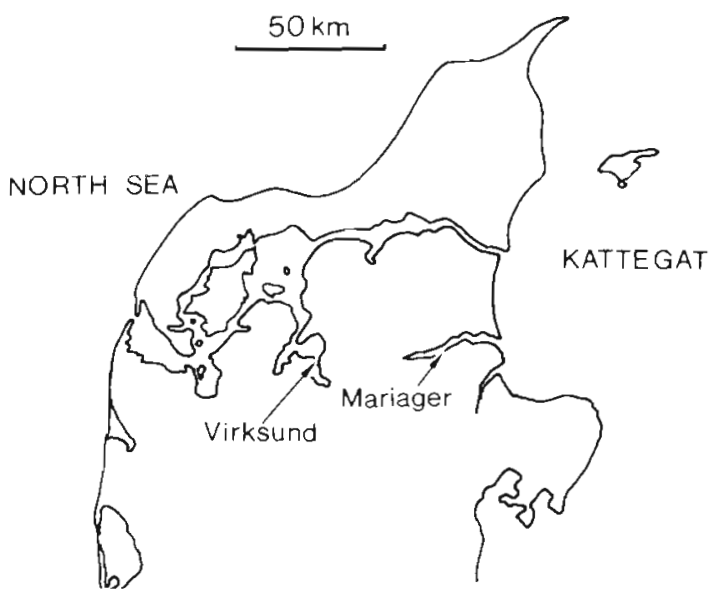

Fig. 1. Map of the northern part of Jutland (Denmark) indicating the location of the sampling stations during the preceding winter and such an oxygenation of the basin may be a regular seasonal event.

The other locality is situated in the Limfjord, a sound running through northern Jutland and connecting the North Sea with the Kattegat. It is an eutrophic water and several basins are periodically or permanently anoxic (Jørgensen 1980). The sampling locality is situated at Virksund (Fig. 1) about $100 \mathrm{~m}$ north of a sluice which separates the Limfjord from a dilute brackish water cove, Hjarbæk Fjord. The water depth is $8 \mathrm{~m}$. Most of the water column has a salinity of ca $22 \%$, but when the sluice is open there is a 1 to $2 \mathrm{~m}$ surface layer consisting of dilute brackish water which flows out from Hjarbæk Fjord (Fig. 2). The locality was sampled on June 25, July 3,17 and 23, and September 25 in 1986. At the first 3 sampling dates the anoxic layer extended 2 to $2.5 \mathrm{~m}$ above the bottom; at the last sample in July it had shrunk to a thickness of only $1 \mathrm{~m}$ and in September the water column was oxygenated throughout. Oxygenation of the bottom water is probably brought about by strong winds; most likely this is facilitated by the breakdown of the thermocline during autumn, but occasional oxygenation of the entire water column probably occurs at intervals throughout the year.

Methods. Samples were taken from an anchored boat with a water sampler (Hydrobios). At Mariager we took samples at $5 \mathrm{~m}$ interval from the surface down to the chemocline; below this depth we sampled at $1 \mathrm{~m}$ intervals. At Virksund, samples were taken from the

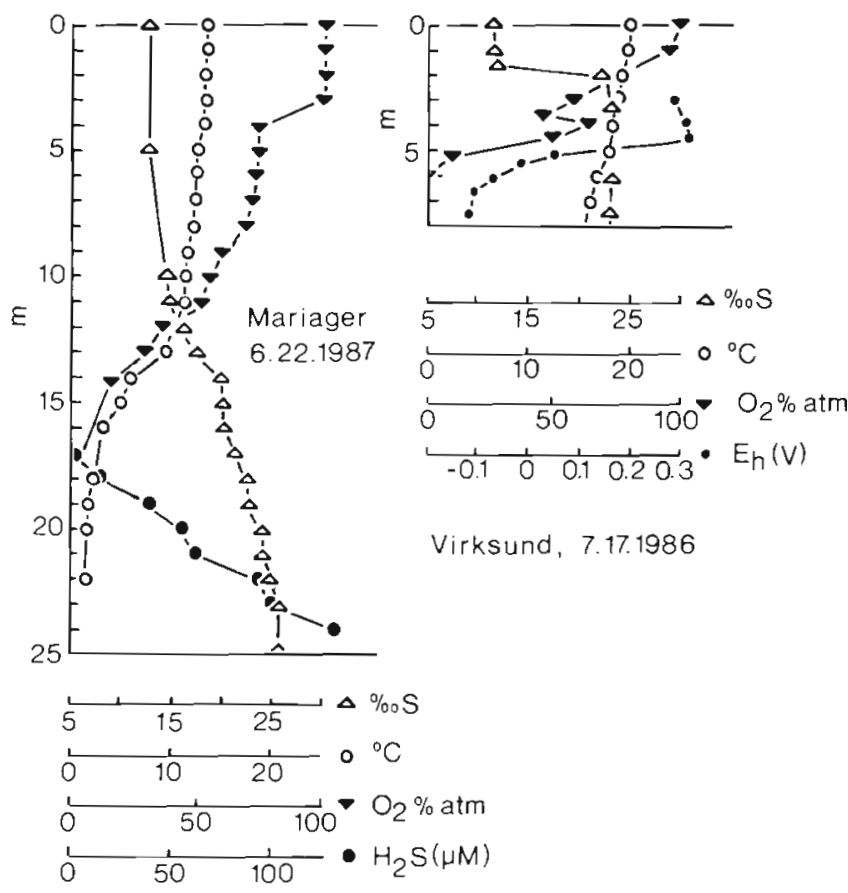

Fig. 2. Examples of vertical profiles of salinity, temperature, oxygen tension, sulphide concentration, and redox potential at the 2 sampling stations 
surface to the bottom at intervals of $0.5 \mathrm{~m}$. Oxygen tension was measured with a submersible oxygen electrode (Yellow Spring Instr.) at Mariager; at Virksund the oxygen content of subsamples was measured by the Winkler method. Hydrogen sulphide was quantified from water samples according to Cline (1969) and redox potentials with a portable $\mathrm{pH}$-meter (Radiometer, Copenhagen) fitted with a platinum electrode (Fenchel 1969).

Bacteria, heterotrophic and autotrophic flagellates and ciliates were enumerated with the epifluorescence microscope following the method of Hobbie et al (1977). Samples were fixed in the field with a solution of acridine orange in formalin. The final concentration of formalin was $1.25 \%$ and that of acridine orange $4 \mathrm{ppm}$ in samples intended for the enumeration of flagellates and bacteria, and $40 \mathrm{ppm}$ for ciliate samples. Bacteria and flagellates were counted on the same filters (Nuclepore, $0.2 \mu \mathrm{m}$ ) based on the filtration of 5 or $10 \mathrm{ml}$ samples. Ciliates were enumerated on $5 \mu \mathrm{m}$ Nuclepore filters and 20 or $50 \mathrm{ml}$ water were filtered. At least 200 bacteria and 40 flagellates and ciliates were counted on each filter. We did not look for small rhizopods and our methods are not quite adequate for such organisms. Autotrophic flagellates were distinguished on the basis of the red autofluorescence of chlorophyll. Comparisons with living ciliates from parallel wwater samples allowed for the identification of most ciliates on the filters to specific or generic level. Classification according to food preferences of different species of ciliates is based on Fenchel (1968) and Andersen \& Sørensen (1986).

Bacteria and flagellates were measured on the filters and grouped in size classes in order to estimate biovolume. In the case of ciliates the length and diameter of individual species were measured and it was assumed that they have an ellipsoidal shape. These results are here presented as g organic carbon, assuming $0.09 \mathrm{~g} \mathrm{C} \mathrm{ml}^{-1}$ for bacteria (Ferguson \& Rublee 1976) and $0.07 \mathrm{~g} \mathrm{C} \mathrm{ml}^{-1}$ for protozoa (Fenchel \& Finlay 1983).

\section{RESULTS AND DISCUSSION}

\section{Qualitative distribution of protozoa}

Table 1 lists the most important species characteristic of oxygenated surface-waters, the chemocline and the anoxic waters, respectively, for the 2 sampled localities. Figs. 3 to 8 show the vertical distribution patterns of some selected species in the 2 sampled stations.

The assemblage of ciliates in the oxygenated surface waters is dominated by oligotrichs, aloricate forms and during summer and autumn also loricate forms (tintinnids). Various gymnostomes (Didinium sp. and a Proro- don sp.) and the photosynthetic Mesodinium rubrum occur in low numbers although the latter mentioned species showed a mass occurrence at Virksund in September (up to 80 cells $\mathrm{ml}^{-1}$ ). Bacterivorous ciliates (e.g. scuticociliates) are almost absent. This assemblage is quite typical of marine ciliate plankton in the area (Andersen \& Sorensen 1986). Examples of vertical distribution patterns among this group are shown in Figs. 3, 4 and 7,8. Planktonic oligotrichs have a tendency to swim upwards and so concentrate in the upper water layers, although this tendency is counteracted by turbulent mixing (Jonsson 1989). However, in our samples the maximum depth at which these forms occur seems always to be limited by oxygen tensions below 30 to $40 \%$ atm. sat.; when the water became oxygenated at the Virksund station in September, species belonging to this assemblage occurred all the way down to the bottom (Fig. 8). However, there is a correlation between turbulent mixing and the depth of the oxycline so no firlal conclusions can be drawn concerning the behavioural response of planktonic oligotrichs to oxygen tension before laboratory experiments have been carried out. There is often a tendency for these forms to accumulate in the maximum density gradient (Fig. 3); this was also observed and discussed by Jonsson (1989). The effect can be explained as the combination of the tendency of these ciliates to swim upwards

Table 1. The common ciliates of the oxygenated surface waters, of the oxycline and of the anoxic zone

\section{MARTAGER LOCALITY}

Surface layer. Oligotrichida: Strombidium sp., Lohmaniella oviformis, $l$. spiralis, Tintinnopsis parvula, T. beroidea, Helicostomella subulata, an unidentified tintinnid. Gymnostomatida: Didinium sp., Mesodinium rubrum

Oxycline. Scuticociliatida: Pleuronema sp., Cyclidium citrullus. Hypotrichida: Euplotes sp., Uronychia transfuga. Heterotrichida: Peritromus sp. Gymnostomatida: Prorodon sp. Hymenostomatida: Frontonia sp.

Anoxic zone. Trichostomatida: Plagiopyla frontata.

Heterotrichida: Metopus contortus, Caenomorpha (levanderi). Odontostomatida: Saprodinium halophila. Gymnostomatida: Lacrymaria sp., an unidentified species. Hymenostomatida: Frontonia sp.

\section{VIRKSUND LOCALITY}

Surface layer. Oligotrichida: Strombidium sp., Lohmanniella oviformis, Tintinnopsis minuta, Tintinnopsis sp., Helicostomella subulata, Favella sp. Gymnostomatida: Mesodinium rubrum, an unidentified species

Oxycline. Scuticociliatida: Cyclidium citrullus,

Pleuronemasp., Oligotrichida: Strombidium sulcatum. Gymnostomatida: Prorodon sp., Didinium sp.

Anoxic zone. Trichostomatida: Plagiopyla frontata. Heterotrichida: Metopus contortus. Scuticociliatida: Cyclidium citrullus. Unidentified Gymnostomatida 


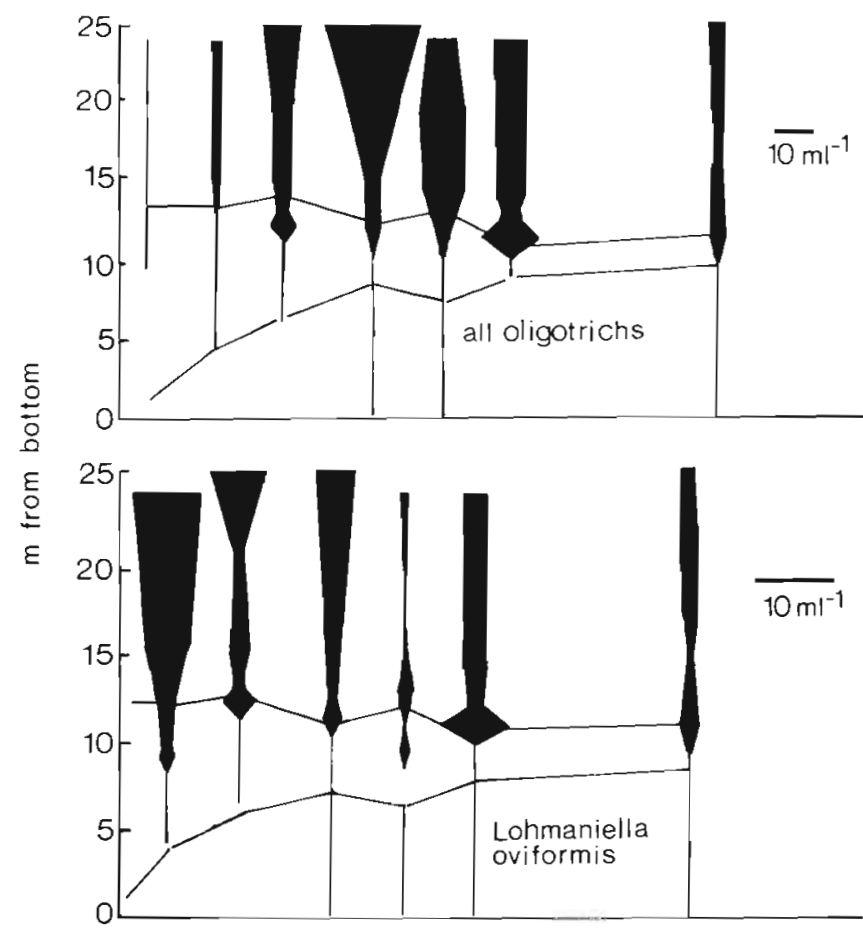

Fig. 3. Vertical distribution of all oligotrichs and of Lohmaniella oviformis at Mariager from the 6 samplings between April and September, 1987. Lines delimit the oxycline $\left(\mathrm{pO}_{2}\right.$ from ca 40 and to $0 \%$ atm)

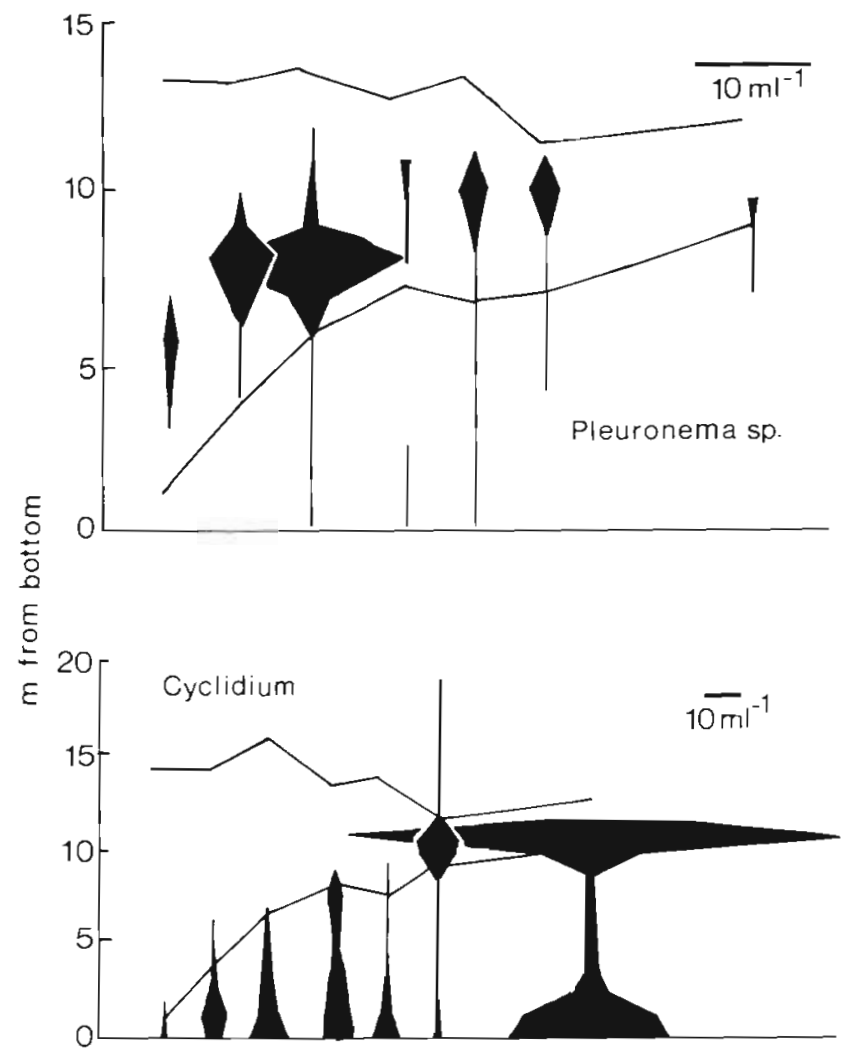

Fig. 4. Vertical distribution of Pleuronema sp. and of $\mathrm{Cy}$ clidium citrullus. Legend otherwise as for Fig. 3 and the reduced turbulent mixing in and below the density gradient layer.

In the oxycline, $\left(\mathrm{pO}_{2}\right.$ ranging between 0 and $40 \%$ atm) a quite different assemblage of ciliates occur. In most periods 2 bacterivorous scuticociliates, Cyclidium citrullus and Pleuronema sp. dominate (Figs. 4 and 7 ). Also common are some gymnostomes including a Prorodon sp. At Mariager, Euplotes sp., Uronychia transfuga, and Peritromus sp. are common, while at Virksund the oligotrich Strombidium sulcatum occurs in large numbers. The occurrence of the heterotrophic dinoflagellate Gyrodinium sp. in the oxycline of Mariager (Fig. 5) should also be noted; the congener $G$. spirale occurs exclusively in the oxygenated surface layers of this locality.

The organisms of the oxycline are probably microaerophiles and their vertical distribution is controlled by oxygen tension. Microaerophily has been established in an Euplotes sp., in the limnic Loxodes spp. and in some other forms (Finlay et al. 1986, Fenchel et al. 1989 and references therein). Also Cyclidium citrullus and Pleuronema spp. accumulate at a $\mathrm{pO}_{2}$ of ca $5 \%$ atm. sat. in experimental oxygen gradients in the laboratory (T. Fenchel unpubl. obs.). These species all show a chemosensory response to oxygen tension, but seem to be indifferent to other correlates of oxygen tension in nature $\left(\mathrm{CO}_{2}\right.$, reduced/oxidised $\mathrm{Fe}, \mathrm{HS}^{-}$, redox potential). Common to the species studied in the laboratory is a reduced survival or growth rate at

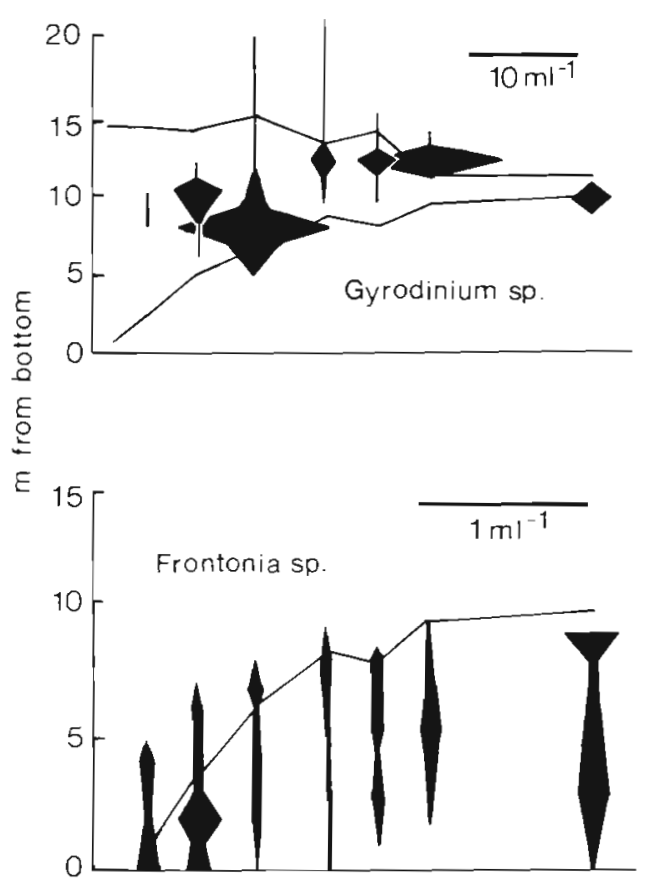

Fig. 5. Vertical distribution of the heterotroph dinoflagellate Gyrodinium sp. and of Frontonia sp. Legend otherwise as for Fig. 3 
higher oxygen tensions, but a considerable tolerance to anoxia although they cannot grow or only grow very slowly under such conditions. The occurrence of the oligotrich Strombidum sulcatum is remarkable in that it is the only 'plankton-type' ciliate in this stratum; the other inhabitants are largely species that normally occur in or on the sediment surfaces, in detrital material and similar habitats. However, Fenchel \& Jonsson (1988) concluded, on the basis of its behaviour in the laboratory, that $S$. sulcatum occurs on or in the immediate vicinity of the sediment surface in nature.

The ciliate assemblage of the chemocline is also characteristic in that bacterivorous forms are common and often quantitatively dominating. The ciliates of the oxygenated surface layers are predominantly feeding on flagellates and microalgae (the oligotrichs); in addition some forms (the gymnostomes) are predators on other ciliates and finally at least one form (Mesodinium rubrum) depends on its endosymbiont algae; bacterivory, on the other hand, is almost exclusively carried out by heterotrophic microflagellates. The importance of bacterivorous ciliates in the oxycline reflects the fact that the bacteria are larger in this zone and that bacterial productivity is likely to show a maximum here; this is discussed in more detail below.

The anoxic zone harbours a special protozoan assemblage. Some of the ciliates (notably Cyclidium citrullus, see Figs. 4 and 7) which have their main distribution in the chemocline may also form dense populations here. In the case of Cyclidium, however, we are not quite confident whether, in fact, there were 2 different species; small scuticociliates are very dif-

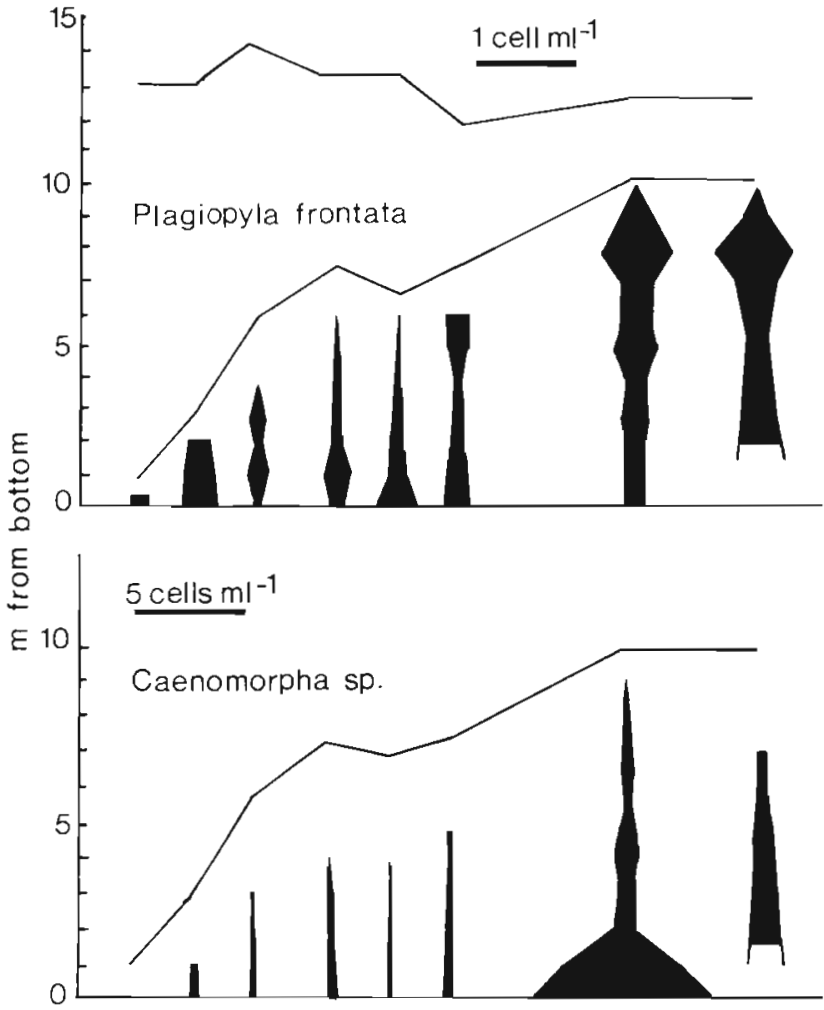

Fig. 6. Vertical distribution of Plagiopyla frontata and Caenomorpha (levanderi?). Legend otherwise as for Fig. 3

ficult to identify at the specific level and a genuine anaerobe belonging to the related genus Cristigera has recently been isolated (Fenchel unpubl. obs.). Otherwise, most of the dominating species of ciliates found in the anoxic layer have previously been established as
Fig. 7. Vertical oxygen profile and zonation of some of the common ciliates at Virksund on July 23, 1986

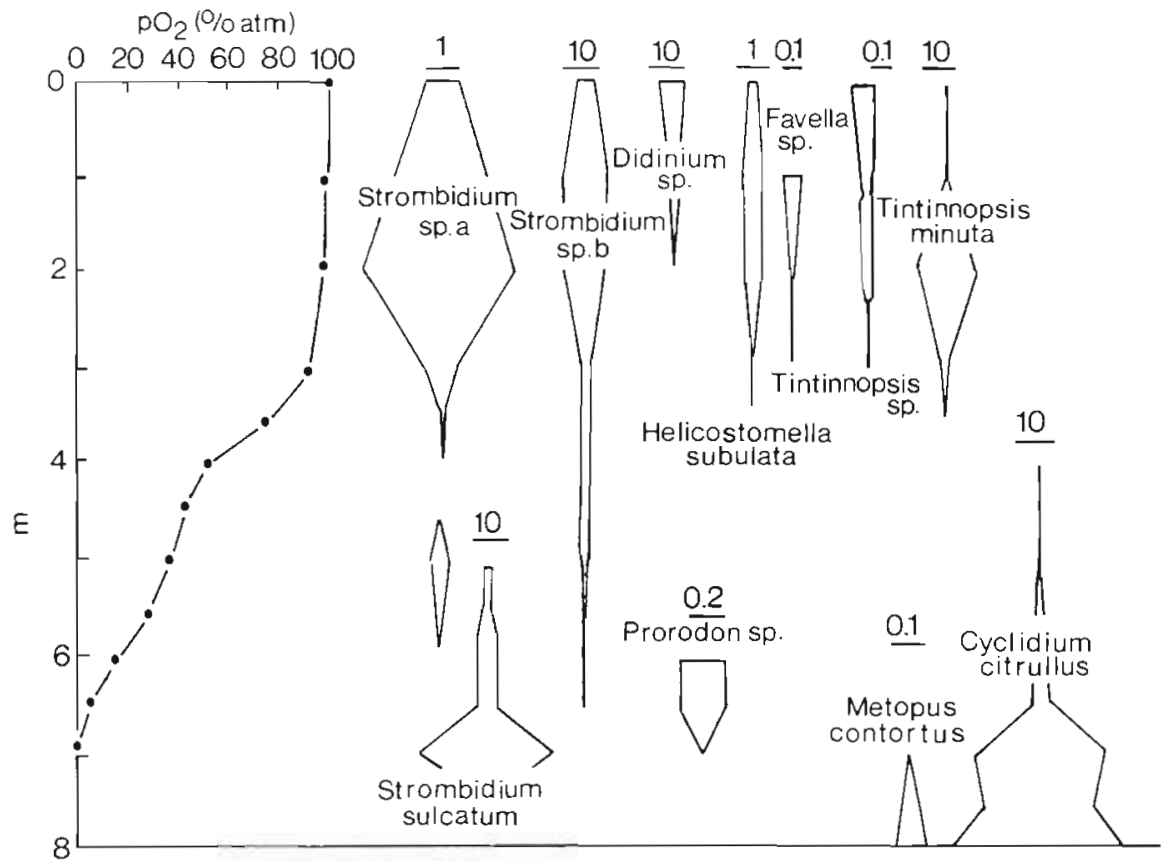




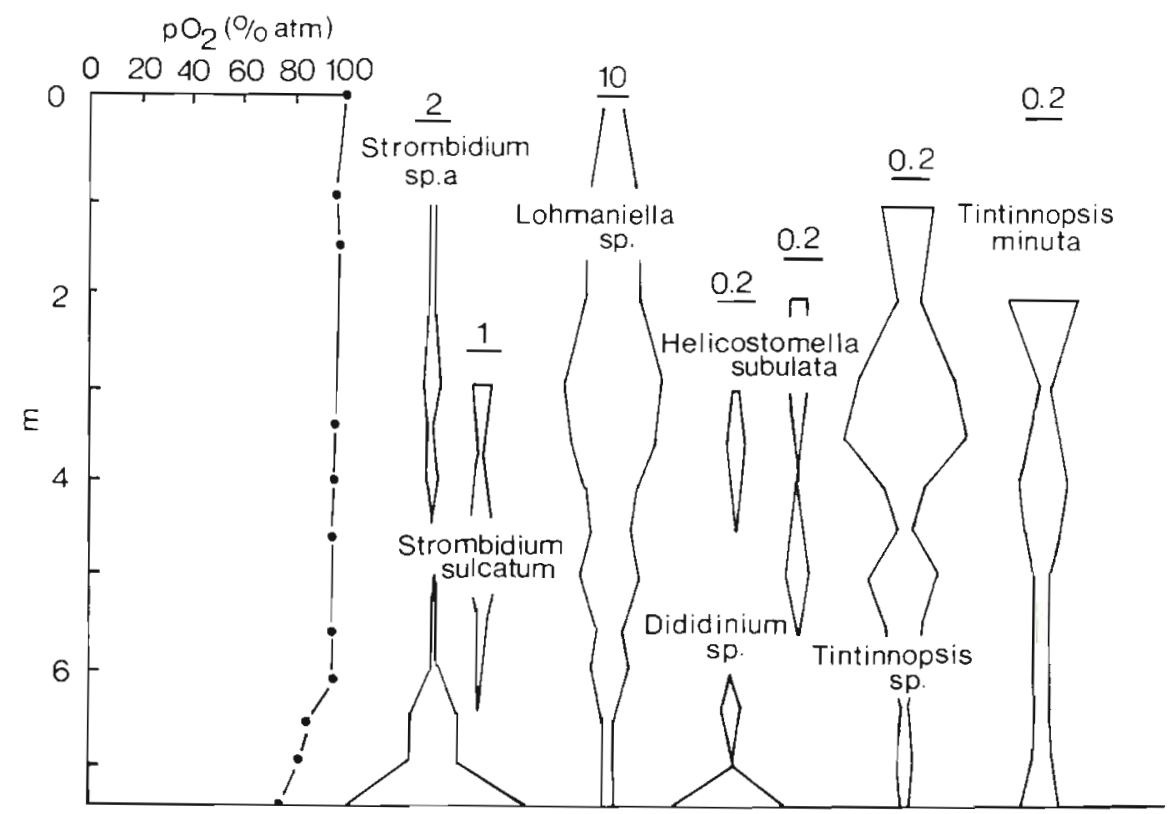

Fig. 8. Vertical oxygen profile and zonation of some of the common ciliate species at Virksund on September 25. 1986

obligatory anaerobes in the laboratory (Fenchel et al. 1977, Van Bruggen et al. 1986, Goosen et al. 1988 Finlay \& Fenchel 1989). These species do not have normal mitochondria; their energy metabolism depends on fermentation, with acetate and hydrogen as endproducts, and many harbour methanogenic endosymbionts. Their growth and survival is inhibited by very low levels of oxygen. In Virksund, Metopus contortus dominates while Plagiopyla frontata and Caenomorpha cf. levanderi form the highest population densities at Mariager; Saprodinium halophila always occurs in small numbers. Fig. 6 shows how 2 representatives of this group of ciliates remain in the strictly anaerobe part of the water column.

Among other ciliates of the anoxic zone a species of Frontonia was found (Fig.5), this genus seems to include anaerobic species (Fenchel 1969) although no experimental evidence exist. Among some gymnostomes a species of Lacrymaria was most common. This latter genus includes at least one anaerobe ( $L$. elegans) that harbours endosymbiont methanogenic bacteria (Fenchel unpubl. obs.). The gymnostomes are the carnivores of this community.

Unfortunately, we were not able to study the vertical distribution of the heterotrophic flagellates from a qualitative point of view in any detail. These organisms are most numerous in the oxygenated surface waters although they sometimes also show a maximum peak of abundance in the chemocline (Fig. 11). They do occur in the anaerobic zone at a relatively low population density Microscopic observations suggest that the anoxic layer harbours a qualitatively different assemblage of species including representatives of the diplomonad flagellates; in the oxic layer the important groups are chrysomonads, bicoecids, choanoflagellates as generally found in marine plankton (Fenchel 1986).

\section{Vertical distribution of bacteria and of bacterivorous protozoa}

The concentration of bacteria remains fairly constant from the surface and down to the sediment surface in terms of number of cells (usually between 1 and $2 \times 10^{6}$ $\mathrm{ml}^{-1}$ ) although a small abundance peak in the oxycline is evident for some sampling dates (Fig. 9). When biomass is considered, however, there is a significant increase from the chemocline and downwards through the anoxic zone. This is due to the fact that the average size of bacteria increases with depth: in the oxygenated zone the average volume is 0.1 to $0.2 \mathrm{um}^{3}$ (which is typical for marine plankton bacteria); in the chemocline the cells are about twice as large, and in the anoxic zone they are ca 5 times larger (Fig. 10). This pattern is evident for both sampling localities. In the chemocline this effect may reflect a more rapid growth of bacteria, but in general we cannot offer an explanation.

Bacterial numbers do not reveal any dramatic changes in biological activities as a function of depth in the water column. This, however, is the case when protozoan abundance is considered (Figs. 11 to 13). This is particularly evident when the vertical distribution of ciliate biomass in Mariager is considered (Fig. 12). The prominent maximum of ciliates in the chemocline is predominantly due to bacterivorous species which are almost absent in the oxygenated surface waters. In the anoxic zone bacterivorous ciliates are 


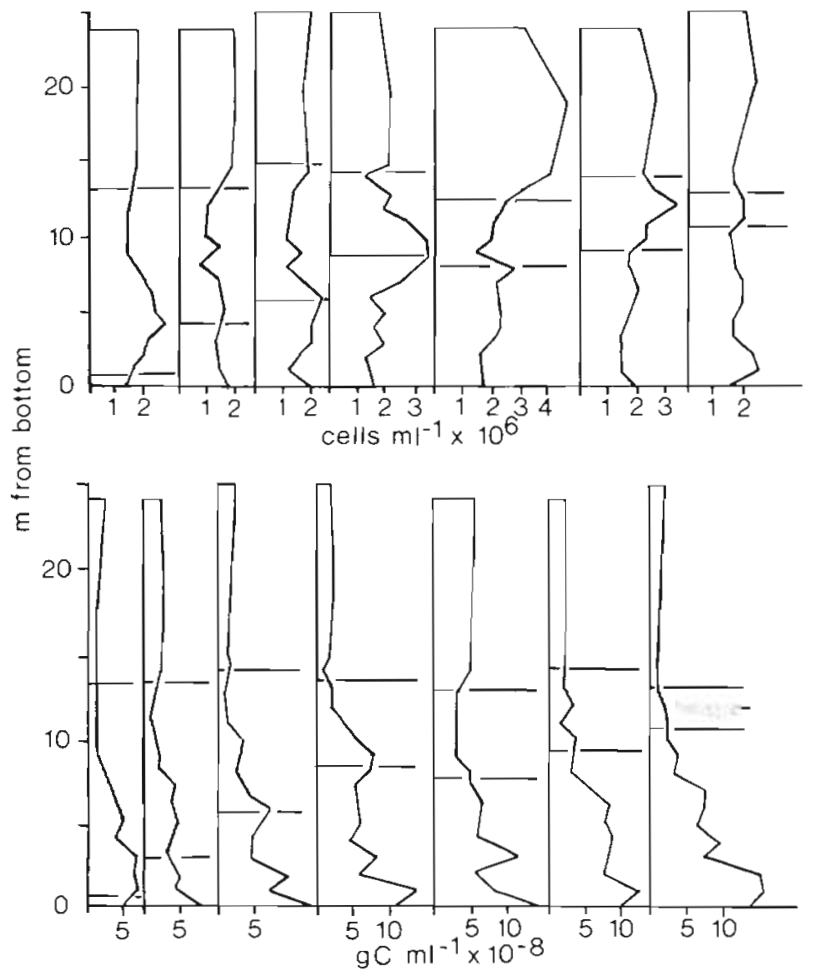

Fig. 9. Vertical distribution of bacterial numbers and bacterial biomass at Mariager for 7 samples taken between April and

November, 1987. Shaded area represents the oxycline

also dominating. Bacterivorous flagellates are abundant in the surface layers, but in most cases they also show an additional peak of abundance in the chemocline. In Virksund the pattern is not so pretty and at one sampling occasion a peak abundance of ciliates in the chemocline was absent (Fig. 13); this can probably be ascribed to the more transient nature of the chemical zonation and of the anoxic zone at this locality.

The presence of an anoxic zone reflects that the

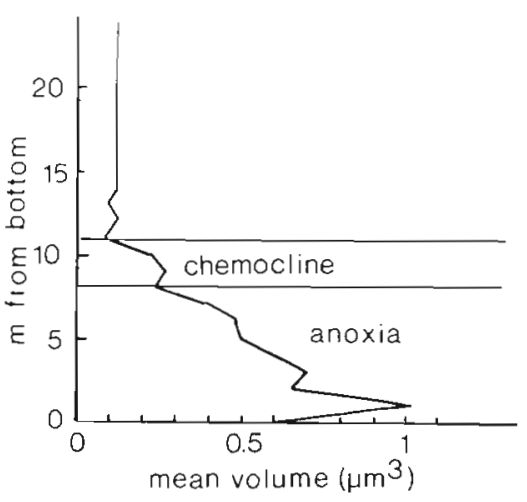

Fig. 10. Average cell volume of suspended bacteria as function of depth at Mariager on August 3, 1987

deposition of dead organic material is in excess of the vertical transport of oxygen required for aerobic mineralisation. The material is, therefore, broken down anaerobically (mainly through fermentation, sulphate reduction and possibly methanogenesis). Where the endproducts of these processes (notably sulphide, but also methane and ammonia) reach an oxygen containing zone they constitute the basis for a substantial bacterial production. In the case of water columns with a chemocline this has been demonstrated by e.g. Sorokin (1972), Indrebø et al. (1979) and Jørgensen et al. (1979). The present study exemplifies that the increased bacterial production in the chemocline may be reflected mainly by an increased biomass of bacterivorous organisms; the fact that bacterial numbers are not much higher in this stratum than elsewhere in the water column supports the idea that they are everywhere controlled by grazing.

In the anoxic zone the protozoan community is
Fig. 11 Vertical distribution of heterotrophic microflagellates at Mariager for 6 samples taken between April and September, 1987. Shaded area represents the oxycline

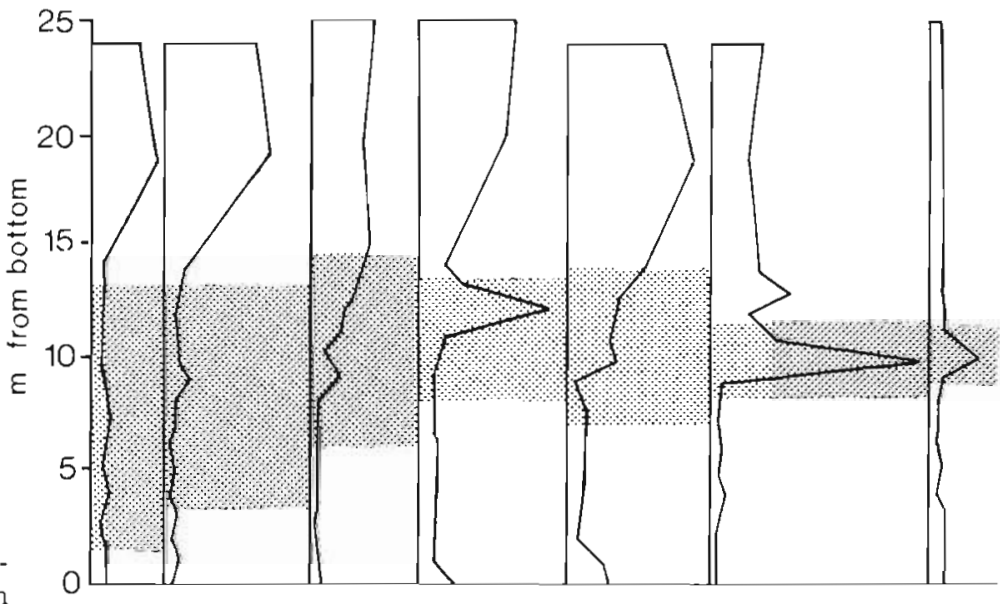

$10^{3} \overline{\text { cells }} \mathrm{ml}^{-1}$ 


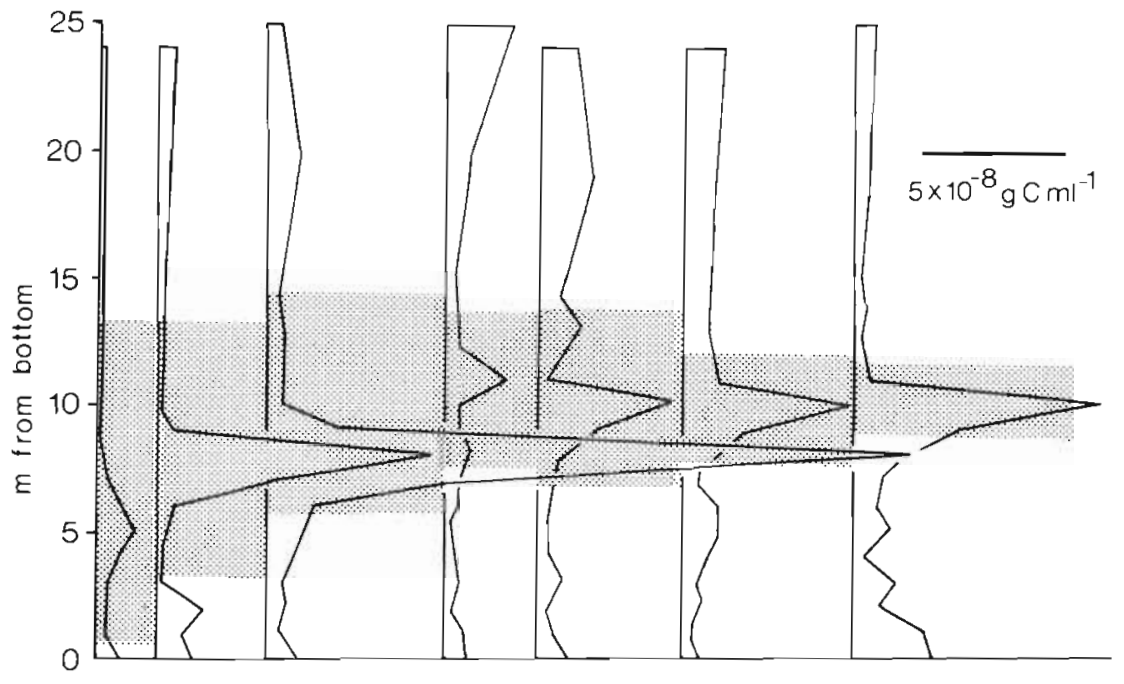

Fig. 12. Ciliate biomass as function of depth for 6 samples taken between April and September, 1987 at Mariager Shaded area represents the oxycline

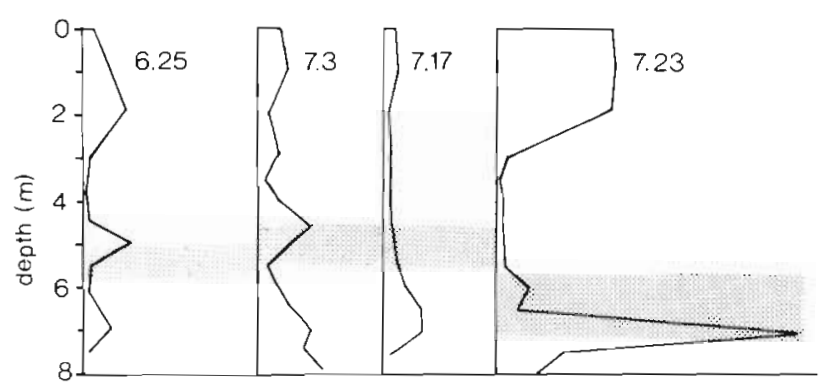

$$
\overline{10^{-8} \mathrm{gC} \mathrm{ml}}{ }^{-1}
$$

Fig. 13. Ciliate biomass as function of depth at Virksund for 4 samples where an anoxic bottom layer was developed. Shaded area represents the oxycline

largely dependent on bacteria. Anaerobic protozoa using fermentative processes for their energy metabolism, must have a lower net growth efficiency than their aerobic relatives. This has not been studied in detail, but the ATP yield of fermentation cannot be higher than $10 \%$ of that of aerobic ATP yield per unit substrate. Calculations based on the assumption that 1 mole of ATP is required for the synthesis of $5 \mathrm{~g}$ cell carbon shows that the net growth efficiency of anaerobes is ca $20 \%$ of that of aerobes. We can, therefore, predict that in an anaerobic community the biomass ratio between phagotrophs and their prey should be about 5 times lower than in aerobic communities (assuming that food particle capture is equally efficient in aerobic and in anaerobic phagotrophs and that they have similar rates of mortality).

Table 2 shows the biomass of bacteria and for bacterivores (bacterivorous ciliates + heterotrophic flagellates) for the oxygenated surface layer, the oxycline and for the anaerobic zone. It also shows the ratios between bacterial and bacterivore biomasses. These tend to fluctuate and this could be expected since the system is never in a steady state and the plankton of such eutrophic waters is characterised by oscillations in population sizes of microbial predators and of their prey organisms (Andersen \& Sørensen 1986, Fenchel, 1986). Even so, the table shows that the biomass ratio between bacterivorous protozoa and bacteria is on the average much lower in the anoxic zone than in the 2 other zones of the water column. The 3 strata were tested by a paired $t$-test after transformation of the ratios to the form $\ln (x+1)$ to reduce heterogeneity of variance. Probabilities that the ratios surface:anoxic and oxycline: anoxic are unity are $<0.01$ and $<0.05$, respectively. It must be a fundamental property of food chains in anaerobic environments that the biomass ratios between predator and prey is lower than in aerobic environments.

\section{Further perspectives}

Until now eukaryote plankton of marine anaerobic waters has been almost ignored; indeed many authors have implied the total absence of 'higher life' in anaerobic (and to some extent microaerobic) environments. As far as metazoa are concerned this may almost be true, but protozoa occur in such environments and play an important role as phagotrophs. With the exception of some of the ciliates these forms have hardly been studied at alli many interesting flagellates and perhaps rhizopods are likely to be discovered and with them interesting adaptations regarding energy metabolism and symbiotic relationships with bacteria.

A special interest should be invested in the role of symbiotic methanogenesis. It is generally held (e.g. Zehnder 1988) that in the sea, methanogenesis take 
Table 2. The biomass ( $\mu \mathrm{g} \mathrm{Cl}^{-1}$ ) of bacteria and bacterivores, and the ratio between bacterivore and bacterial biomasses for the surface layers, oxycline and anoxic zone, respectively at the Mariager locality

\begin{tabular}{|c|c|c|c|c|c|c|c|c|c|}
\hline \multirow[t]{2}{*}{ Layer } & \multicolumn{7}{|c|}{ Date (1987) } & \multirow[t]{2}{*}{ Mean } & \multirow[t]{2}{*}{$\mathrm{SD}$} \\
\hline & $14 \mathrm{Apr}$ & 2 May & $22 \mathrm{May}$ & 22 Jun & $12 \mathrm{Jul}$ & 3 Aug & $6 \mathrm{Oct}$ & & \\
\hline \multicolumn{10}{|l|}{ Bacteria } \\
\hline Surface & 20 & 28 & 20 & 18 & 51 & 24 & 14 & 25.0 & 12.3 \\
\hline Oxycline & 46 & 28 & 31 & 54 & 48 & 45 & 32 & 40.6 & 10.1 \\
\hline Anoxic & 50 & 57 & 81 & 69 & 89 & 91 & 97 & 76.3 & 18.0 \\
\hline \multicolumn{10}{|c|}{ Bacterivores } \\
\hline Surface & 3.2 & 6.2 & 6.6 & 6.7 & 13.3 & 13.5 & 1.6 & 7.3 & 4.6 \\
\hline Oxycline & 4.0 & 15.8 & 49.6 & 7.9 & 7.0 & 9.0 & 44.1 & 19.6 & 19.0 \\
\hline Anoxic & 4.7 & 5.6 & 6.2 & 4.3 & 4.3 & 3.8 & 11.3 & 5.7 & 2.6 \\
\hline \multicolumn{10}{|l|}{ Ratio } \\
\hline Surface & 0.16 & 0.22 & 0.32 & 0.38 & 0.26 & 0.56 & 0.12 & 0.29 & 0.15 \\
\hline Oxycline & 0.09 & 0.56 & 1.6 & 0.14 & 0.16 & 0.20 & 1.39 & 0.59 & 0.64 \\
\hline Anoxic & 0.09 & 0.10 & 0.08 & 0.06 & 0.06 & 0.04 & 0.12 & 0.08 & 0.03 \\
\hline
\end{tabular}

place only when sulphate has been depleted by sulphate-respiring bacteria and this usually occurs only at a considerable depth in the sediment. However, many of the anaerobic protozoa in the water column harbour methanogenic bacteria depending on hydrogen which is a metabolic endproduct of the protozoa. Species like Metopus and Plagiopyla harbour 1 to $5 \times 10^{4}$ methanogens cell ${ }^{-1}$ (Finlay \& Fenchel 1989). During this investigation we frequently found ca 10 cells $\mathrm{ml}^{-1}$ of such forms so that the symbiontic methanogens may account for 5 to $25 \%$ of all the bacteria present in anoxic water.

Acknowledgements. We thank Per Andersen and Helene Munk Sorensen for discussions and information on microplankton of the Limfjord. We are also grateful to Peter Leineweber for suggestions and for assistance during field work at the Mariager Fjord locality.

\section{LITERATURE CITED}

Andersen, P., Sørensen, H. M. (1986). Population dynamics and trophic coupling in pelagic microorganisms in eutrophic coastal waters. Mar. Ecol. Prog. Ser. 33: 99-109

Bark, A. W. (1981). The temporal and spatial distribution of planktonic and benthic protozoan communities in a small productive lake. Hydrobiologia 85: 239-255

Cline, J. D. (1969). Spectrophotometric determination of hydrogen sulfide in natural waters. Limnol. Oceanogr. 14: $454-458$

Fenchel, T. (1968). The ecology of marine microbenthos II. The food of marine benthic ciliates. Ophelia 4: 73-121

Fenchel, T. (1969). The ecology of marine microbenthos IV Structure and function of the benthic ecosystem, its chemical and physical factors and the microfauna communities with special reference to the ciliated protozoa. Ophelia 6 : $1-182$

Fenchel, T (1986). The ecology of heterotrophic microflagellates. Adv. microb. Ecol. 9: 57-97
Fenchel, T., Finlay, B. J. (1983). Respiration rates in heterotrophic, free-living protozoa. Microb. Ecol, 9: 99-122

Fenchel, T., Finlay, B. J., Gianni, A. (1989). Microaerophily in ciliates: responses of an Euplotes species (Hypotrichida) to oxygen tension. Arch. Protistenk. 137: 317-330

Fenchel, T., Jonsson, P. R. (1988). The functional biology of Strombidium sulcatum, a marine oligotrich ciliate (Ciliophora, Oligotrichina). Mar Ecol. Prog. Ser. 48: 1-15

Fenchel, T., Perry, T., Thane, A. (1977). Anaerobiosis and symbiosis with bacteria in free-living ciliates. J. Protozool. 24: $154-163$

Ferguson, R. L., Rublee, P. (1976). Contribution of bacteria to standing crop of coastal plankton. Limnol. Oceanogr. 21. $141-145$

Finlay, B. J. (1980). Temporal and vertical distribution of ciliophoran communities in the benthos of a small eutrophic loch with particular reference to the redox profile. Freshwat. Biol. 10: 15-34

Finlay, B. J. (1981), Oxygen availability and seasonal migrations of ciliated protozoa in a freshwater lake. J. gen. Microbiol. 123: 173-178

Finlay, B. J., Fenchel, T. (1989). Hydrogenosomes in some anaerobic protozoa resemble mitochondria. Fedn eur. microbiol. Soc. (FEMS) Lett. 65: 311-314

Finlay, B. J., Fenchel, T., Gardener, S. (1986). Oxygen perception and $\mathrm{O}_{2}$ toxicity in the freshwater ciliated protozoon Loxodes. Protozool. 33: 157-165

Goosen, N. K., Horemanns, A. M. C., Hillebrand, S. J. W., Stumm, C. K., Vogels, G. D. (1988). Cultivation of the sapropelic ciliate Plagiopyla nasuta Stein and isolation of the endosymbiont Methanobacterium formicicum. Archs Microbiol. 150: 165-170

Goulder, R. (1972). The vertical distribution of ciliated protozoa in the plankton of an eutrophic pond during the summer stratification. Freshwat. Biol. 2: 163-176

Goulder, R. (1974). The seasonal and spatial distribution of some benthic ciliated Protozoa in Esthwaite Water. Freshwat. Biol. 4: 127-147

Hobbie, J. E., Daley, R. J., Jasper, S. (1977). Use of Nuclepore filters for counting bacteria by fluorescence microscopy. Appl. envir. Mircob. 33: 1225-1228

Indrebø, G., Pengerud, B., Dundas, I. (1979). Microbial activities in a permanently stratified estuary. I. Primary production and sulfate reduction. Mar. Biol. 51: 295-304 
Jonsson, P. R. (1989). Vertical distribution of planktonic ciliates - an experimental analysis of swimming behaviour. Mar. Ecol. Prog. Ser. 52: 39-53

Jorgensen, B. B. (1980). Seasonal oxygen depletion in the bottom waters of a Danish fjord and its effect on the benthic community. Oikos 34: 68-76

Jorgensen, B. B., Kuenen, J. G., Cohen, Y (1979). Microbial transformations of sulfur compounds in a stratified lake (Solar Lake, Sinai). Limnol. Oceanogr. 24: 799-822

Kühlmorgen-Hille, G. (1963). Die jahreszeitlichen Veränderungen in der Bodenfauna der Kieler Bucht. Kieler Meeresforsch. 19: 42-67

Oertzen, J.-A. von, Schlungbaum, G. (1972). Experimentellökologische Untersuchungen über $\mathrm{O}_{2}$-Mangel und $\mathrm{H}_{2} \mathrm{~S}$. Resistenz an marinen Evertebraten der westlichen Ostsee. Beitr. Meeresk. 29: 79-91

This article was submitted to the editor
Richards, F. A. (1965). Anoxic basins and fjords. In: Riley, J. P., Skirrow, G. S. (eds.) Chemical oceanography. Academic, New York, p. 611-645

Sorokin, Y. I. (1972). The bacterial population and the process of hydrogen sulphide oxidation in the Black Sea. J. Cons. int. Explor. Mer 34: 423-455

Tulkki, P. (1965). Disappearance of the benthic fauna from the basins of Bornholm (southern Baltic) due to oxygen deficiency. Cah. Biol. mar. 6: 445-463

Van Bruggen, J. J. A., Zwart, K. B., Hermans, J. G. F., van Hove, E. M., Stumm, C. K., Vogels, C. D. (1986). Isolation and characterization of Methanoplanus endosymbiosus sp. nov., an endosymbiont of the marine sapropelic ciliate Metopus contortus. Archs Microbiol. 144: 367-374

Zehnder, J. B. (ed.) (1988). Biology of anaerobic microorganisms. Wiley, New York

Manuscript first received: November 10, 1989

Revised version accepted: January 16, 1990 